\title{
TEORIAS DO ESTADO NO SÉCULO XXI:
}

\section{DA RAZÃO DE ESTADO ÀS FONTES DISRUPTIVAS DO PODER POLÍTICO ${ }^{1}$}

\author{
THEORY OF THE STATE IN THE 21ST CENTURY:
}

FROM STATE REASON TO DISRUPTIVE SOURCES OF POLITICAL POWER

\author{
Vinício Carrilho Martinez ${ }^{2}$ \\ Vinícius Alves Scherch ${ }^{3}$
}

Resumo: O artigo apresenta algumas teorias do Estado no século XXI, com destaque para os aportes teóricos da Razão de Estado e a deformação do Poder Político na prática contemporânea pela utilização da exceção como técnica de governo. Para a elaboração do texto foi usado o método dialético para contrapor concepções de Estado e uma pesquisa do tipo bibliográfico, a partir de autores que têm trabalhos semelhantes. A conclusão obtida é a de que na Modernidade Tardia há poucas aberturas ao novo e que Estado veio se adaptando, consoante antigas práticas, para estabelecer maior força de controle social.

Palavras-chave: Direito líquido; Ditadura Inconstitucional; Estado de exceção; Modernidade Tardia; Teorias do Estado.

Abstract: The article presents some theories of the State in the 21st century, with emphasis on the theoretical contributions of Reason of State and the distortion of Political Power in contemporary practice by using the exception as a government technique. For the elaboration of the text was used the dialectical method to counter conceptions of State and a research of the bibliographic type, from authors who have similar works. The conclusion reached is that in Late Modernity there are few openings to the new and that state has been adapting, according to old practices, to establish a greater force of social control.

Keywords: Liquid Law; Unconstitutional Dictatorship; State of exception; Late modernity; Theories of the State.

\section{Introdução}

O título, em si, já é uma provocação, no sentido da contracorrente de que a chamada pós-modernidade (LYOTARD, 1989) e a globalização (IANNI, 1983) teriam inviabilizado as

\footnotetext{
${ }^{1}$ Artigo submetido em 19/08/2019 e aprovado para publicação em 15/06/2020.

${ }^{2}$ Pós Doutor em Direito e em Ciência Política. Professor Associado da Universidade Federal de São Carlos UFSCar/CECH. ORCID: https://orcid.org/0000-0002-0593-0544.

3 Mestrando em Ciência Jurídica na Universidade Estadual do Norte do Paraná - UENP. ORCID: https://orcid.org/0000-0003-3671-3822.
} 
condições essenciais (soberania) do Estado Moderno. No entanto, nosso objetivo será o de especificar que o Estado Moderno sobrevive no século XXI, com adaptações inclusive que remontam ou recuperam as bases de formação do Estado Hobbesiano (HOBBES, 1983). Bem como sinalizam, em conjunto com as características apresentadas pelo viés econômico e cultural, com a referência de que a modernidade política não esgotou seus recursos - daí preferirmos a denominação Modernidade Tardia (GIDDENS, 2001). Por fim, indicaremos como essa formulação da Teoria do Estado se adequa, em "novos" parâmetros, ao Brasil do pós-2016.

Cabe salientar, inicialmente, que o conceito/realidade da Modernidade Tardia remonta ao Renascimento - e não como se afirma, tradicionalmente, ao Iluminismo - porque é no contexto da concentração do poder sob os auspícios do Estado-Nação (MARTINEZ, 2012) que se evidencia a Razão de Estado. Por sua vez, a Razão de Estado permanece na esteira do Estado e no Direito Moderno, bem como hodiernamente. Por isso, para visualizar a metamorfose da Razão de Estado em Estado de Exceção é necessário verificar as bases teóricas e históricas da Razão de Estado, efetivamente, a fim de notabilizarmos o que se modificou, neste longo período histórico, para que se organizasse a nova estrutura política e jurídica legitimadoras. O Iluminismo, por seu turno, tem um significado essencial (aliado à Razão de Estado renascentista) porque foi no século XVIII, pós-Revolução Francesa, que se verificou a primeira fase da transformação. Neste momento, vimos emergir o famoso expediente político/jurídico do Estado de Sítio.

Metodologicamente, o trabalho é um mix entre um texto ensaístico - com interpretações livres e mais proposições provocativas do que comprovações incorrigíveis do seu objeto (como se fosse possível) - e uma construção teórica baseada em dissertações, desta forma foi utilizado o método dialético, que parte de ideias que são confrontadas para alcançar uma concepção de Estado. A pesquisa empregada para a elaboração do artigo foi do tipo bibliográfica, a partir de leituras que já se converteram em escritas sobre o tema; agora, lhes atribuindo nova interpretação. Assim, cada capítulo é uma dissertação com um objeto característico, mas que se liga ao objeto geral, ainda que entre si os capítulos não estejam ligados sob a estreita lógica positivista. Na verdade, ainda que dividido em cinco capítulos dissertativos, pretende-se um único trabalho interligado, articulando-se as partes em questões de fundo: 1) a modernidade e a afirmação da Razão de Estado (a regra que gerou liberdade, 
autonomia e soberania); 2) a razão posta a serviço da dominação (o exceptio); 3) Alguns argumentos e momentos históricos em que se visualiza a metamorfose da Razão de Estado em Estado de Exceção: a Modernidade Tardia; 4) outras saídas racionais: a autonomia radical e a liberdade; 5) a legitimidade interna ao Estado de Direito que não se furta à previsão e ao uso regular dos meios de exceção.

De outro modo, mais detalhado quanto ao curso burocrático da razão (GIDDENS, 1991), na primeira conversão, dos Códigos de Prudência, passamos à própria razão política laica descrita por Maquiavel (1979). Já na segunda, com o fim do Renascimento e a entrada do Iluminismo, novas regras políticas foram depositadas na conta da humanidade: a começar pelas regras de exceção. Na sequência, a partir da viragem entre os séculos XIX e XX, vimos em Weimar a desculpa que faltava ao totalitário regime de exceção do nazismo. Por fim, nesta espécie de quarta fase, temos pela frente os desafios da privatização da soberania (o que não implica exatamente no fim das fronteiras do Estado-Nação), pelo fenômeno conhecido como Estado Penal. Como recurso analítico do jurídico em que se embute a exceção, vê-se aliás, que seus idealizadores retomaram o jusnaturalismo, Hobbes e Rousseau ${ }^{4}$.

\section{Uma conceituação de modernidade tardia}

Para melhor compreender o que se entende aqui por Modernidade Tardia, locus entre o passado e o futuro, e porque ainda se está preso ao passado ao mesmo tempo que não se consegue olhar diretamente para o futuro - pelo simples fato de que não há projeto de futuro -usar-se-á a metáfora de "La Sagrada Família", do arquiteto catalão Antoni Gaudí.

Iniciada em 1882, a construção foi suspensa no período da Guerra Civil Espanhola, em 1936, e só deverá ser concluída em 2026, no centenário da morte de Gaudí. O projeto é do

\footnotetext{
${ }^{4}$ Hobbes tinha consciência desta situação. Nominalmente, é (também) um teórico do contrato social, mas materialmente é, preferentemente, um filósofo das instituições. Seu contrato de submissão - junto a qual aparece, em igualdade de direito (?) a submissão por meio da violência - não se deve entender tanto como um contrato, mas como uma metáfora de que os (futuros) cidadãos não perturbem o Estado em seu processo de auto-organização [...] Entretanto, a situação é distinta quando se trata de uma rebelião, isto é, de alta traição: Pois a natureza deste crime está na rescisão da submissão, o que significa uma recaída no estado de natureza [...] E aqueles que incorrem em tal delito não são castigados como súditos, mas como inimigos (JAKOBS; MELIÁ, 2005, p. 27).

${ }^{5}$ Essa obra faraônica, digna da melhor representação do engenho matemático e do delírio humano, expressa-se entre o passado, o presente e o futuro. Trata-se de uma ilusão, uma miríade, um cálculo cartesiano, um hino ao infinito, bem como uma saudação ao catolicismo.
} 
século XIX e percorreu todo o século XX sem se ver concluído. O esforço de construção tem sido enorme, uma vez que todas as maquetes foram destruídas na Guerra Civil Espanhola, por esquerdistas que associavam o arquiteto ao clero conservador, absolutista, logo, franquista.

No século XXI, se tudo correr dentro dos planos, será conhecida a conclusão desse projeto informe ainda na terceira década do milênio pós-moderno. É importante ter claro que esse projeto da modernidade deverá ter seu feito anunciado apenas 150 anos depois de desenhado. Todavia, o visual do Templo Expiatório da Sagrada Família é tão surreal quanto sua construção. Todas as tradições deveriam pagar sua cota neste verdadeiro templo da expiação do futuro.

Inegável reconhecer que a Modernidade Tardia é dotada de complexidade temporal e metodológica, que não lhe é possível atribuir linearidade ou uma constante, seja no sentido evolutivo, seja no sentido involutivo. Como evidenciado na Alemanha, ao mesmo tempo que se estruturava a Constituição de Weimar, o nazismo lhe negava os efeitos concretos, numa verdadeira antinomia que legalmente era aceita. A todo custo a noção de soberania do Estado foi mantida, nem que para isso fossem necessários poderes excepcionais.

Em todo caso, quer seja um empréstimo apropriado ou não quanto à soberania ameaçada por delinquentes ou inimigos, Hobbes seria mais explícito quanto à própria soberania necessária à Razão de Estado, ou seja, no lugar do Homem de virtù (MAQUIAVEL, 1979) e regente da Prudência (MAQUIAVEL, 1994), deve consubstanciar-se realmente o Estado como soberano. Portanto, o poder, ainda que absolutista, é menos pessoal ou personalizado ${ }^{6}$.

\footnotetext{
${ }^{6}$ 1. Em primeiro lugar, aqueles que já instituíram um Estado, dado que são obrigados pelo pacto a reconhecer como seus os atos e decisões de alguém, não podem legitimamente celebrar entre si um novo pacto no sentido de obedecer a outrem, sem sua licença. 2. Em segundo lugar é evidente que quem é tornado soberano não faz antecipadamente qualquer pacto com seus súditos, porque teria ou que celebrá-lo com toda a multidão, na qualidade de parte do pacto, ou que celebrar diversos pactos, um com cada um deles. 3. Em terceiro lugar, se a maioria, por voto de consentimento, escolher um soberano, os que tiverem discordado devem passar a consentir juntamente com os restantes ou será deixado na condição de guerra. 4. Em quarto lugar, dado que todo súdito é por instituição autor de todos os atos e decisões do soberano instituído, segue-se que nada do que este faça pode ser considerado injúria para com qualquer dos seus súditos, e que nenhum deles pode acusá-lo de injustiça. 5. Em quinto lugar, aquele que detém o poder soberano não pode justamente ser morto, nem de qualquer outra maneira pode ser punido por seus súditos. 6. Em sexto lugar, compete à soberania ser juiz de quais as opiniões e doutrinas que são contrárias à paz, e quais as que lhe são propícias. Portanto compete ao detentor do poder soberano ser o juiz, ou constituir todos os juízes de opiniões e doutrinas, como uma coisa necessária para a paz, evitando assim a discórdia e a guerra civil. 7. A sétima razão diz que: todo o homem pode saber quais os bens de que pode gozar portanto esta propriedade, dado que é necessária à paz e depende do poder, é um ato desse poder, tendo em vista a paz pública. 8. Em oitavo lugar, pertence ao poder soberano a autoridade judicial, quer dizer, o
} 
A grande diferença entre os possíveis bandidos do passado e os usurpadores do poder está no fato de que, no passado idílico, os mercenários respondiam aos seus generais e, na atualidade, respondem às empresas de matar como a Blackwater (SCHILL, 2008). Portanto, atuam como civis e não respondem ao comando do Estado: literalmente, como nunca se viu na história, a máquina de guerra está acima da lei. Mas, a Modernidade Tardia também é uma luta pela sobrevivência e reinvenção dos clássicos na atualidade, uma luta sem muito esforço porque esse pensamento germinal anteviu a atualidade quando ainda nem era broto.

Esta é a ideia: o percurso da reflexão, em busca da "compreensão" ou da
"explicação", pode levar consigo algo, ou muito, de ficção. A realidade
transfigura-se em conceito e categoria ou em metáfora e alegoria. Estas
metamorfoses são frequentes, às vezes inevitáveis. Há sempre algum contraponto
entre elas. Aliás, são frequentes os casos de metáforas que adquirem o
significado de conceitos, assim como há casos em que conceitos se transfiguram
em metáforas. Mas é inegável que essas podem ser modulações do conhecimento.
Sim, a metáfora e a alegoria também podem ser formas de conhecimento, meios
e modos de alcançar o esclarecimento. (IANNI, 2002 - grifos nossos)

Na verdade, estava e está em curso um uso estratégico da razão: um uso específico da razão instrumental no mundo social em relação a outros sujeitos, para fins de manipulação ou controle, se observarmos a Sociedade de Controle (DELEUZE, 1992). Este uso instrumental ou estratégico predomina porque é empregado para conservar o poder - trata-se do uso da racionalidade com vistas a fins (WEBER, 1979), sem se considerar os meios inerentes à soberania popular, por exemplo, e como se teria a seguir a máxima do potestas in populo e que era subjacente ao Iluminismo.

\section{Teorias do Estado: dos clássicos ao século XXI}

direito de ouvir e julgar todas as controvérsias que possam surgir. 9. Em nono lugar, pertence à soberania o direito de fazer a guerra e a paz com outros Estados. 10. Em décimo lugar, compete à soberania a escolha de todos os conselheiros, ministros, magistrados e funcionários. 11. Em décimo primeiro lugar, é confiado ao soberano o direito de recompensar com riquezas e honras, e o de punir com castigos corporais ou pecuniários, de acordo com a lei que previamente estabeleceu. 12 Por último [...] Ao soberano compete pois também conceder títulos de honra, e decidir qual a ordem de lugar e dignidade que cabe a cada um (HOBBES, 1983). 
Somente com a Paz de Vestfália ${ }^{7}$, em 1648, é que o Estado passou a ser reconhecido pelo tripé Povo-Território-Soberania e assim transformou-se, na doutrina, de uma Filosofia do Estado para a real constituição de uma Teoria Geral do Estado (TGE). A Paz de Vestfália deu início, juridicamente falando, ao Estado Moderno $^{8}$ (ou Ocidental, como modelo a ser seguido pelo mundo colonizado) e à ciência inaugural da Teoria Geral do Estado. É certo que se pode falar de vários Estados e de suas interpretações ideológicas - como se fosse obrigado a se render ao pluralismo das tipologias e das "Teorias do Estado" -; contudo, sob a marcação histórica do territorium clausum $^{9}$, formou-se - com validade epistemológica - uma nova Teoria Geral do Estado. Por fim, pode-se dizer que não é uma ciência derivada, de objeto filosófico ou especulativo; constitui-se em ciência social autônoma e com objeto por demais definido: a articulação historicamente analisada entre Povo, Território e Soberania. Por delimitação epistemológica das grandes áreas do conhecimento, rendeu-se mais às atribuições do Direito e dos juristas, do que à Ciência Política e aos cientistas sociais. A real diferença entre as hordas do passado, das comunidades primitivas e/ou indígenas e o Renascimento, que deu vida nova ao Poder Político, está na fabricação do intitulado Poder Extroverso pelo Estado Moderno. Com a nova forma-Estado instituída, era necessário ter a Ciência do Direito uma correspondência na teoria e na doutrina do Poder Político.

\subsection{Teoria Geral do Estado}

\footnotetext{
${ }^{7}$ Conjunto de tratados de paz, reconhecendo-se a Confederação Suíça e pondo fím à Guerra dos Trinta Anos, estabeleceram-se as respectivas regiões limítrofes e assim passaram a indicar o território como um elemento ou componente formal de dois Estados contíguos. Esta pode ser entendida como a data de nascimento do Estado Moderno, pois houve a fixação formal do território e da soberania do povo ali residente (territorium clausum): "O que na verdade o Estado detém sobre o território é a sua jurisdição, da qual este serve como limite, e qualquer alteração territorial de um Estado é sempre um fato de grande relevância, perante si próprio e até perante a ordem internacional (BASTOS, 1994, p. 209). Trata-se do Imperium: o poder de mandar.

${ }^{8}$ Nosso modelo de Ciência Política e de Teoria Geral do Estado, tirando-se as "atualizações" e a historicidade, permanece copiando a fórmula do Renascimento: "Só tem o direito de considerar completada sua educação quando se puder falar que ele — como diz Ofélia a respeito de Hamlet — conseguiu bem combinar 'o olho do cortesão, a língua do letrado, o gládio do guerreiro" (SKINNER, 1996, p. 112). Com Hamlet vemos a submissão do homem político como devotado servo da Razão de Estado - um homem que deve abrir mão da sua vontade pela vontade política: "LAERTES / Ele é um nobre, e assim sua vontade / Não lhe pertence, mas à sua estirpe / Ele não pode, qual os sem valia / Escolher seu destino: dessa escolha / Dependem segurança e bem do Estado / Assim, o seu desejo se submete / À voz e ao comando desse corpo / Do qual ele é a cabeça. Se ele afirma / Que tem ama, cabe a ti acreditar / Somente no que possam permitir / A sua posição e a Dinamarca" (SHAKESPEARE, 2004, p.163 - grifo nosso).

${ }^{9}$ No campo jurídico-político, o Estado Absolutista é a primeira manifestação do territorium clausum, dentro do qual o monarca possui o monopólio da violência (COTARELO, 2004, p. 19).
} 
A Teoria Geral do Estado nasceu a partir da necessidade de se analisar o surgimento do Estado Moderno, como novo fenômeno jurídico-político da maior grandeza; como doutrina, foi sistematizada no século XIX, na Alemanha, por Jellinek (2000). Comparativamente, a Ciência política corresponde à investigação empírica do poder, já no clássico Renascimento italiano do século XVI, e iniciada por Maquiavel. A Teoria Geral do Estado (TGE) se apoiaria nas análises do chamado realismo político, mas com o objetivo de superar as restrições impostas pela Filosofia do Estado.

Como Filosofia do Estado se entende, muitas vezes, a definição meramente moral das instituições de poder, sem que se avalie com realismo a condução das mesmas. Com isso, as Teorias do Estado passariam a observar os elementos de permanência e de constância na formação do Poder Político. Epistemologicamente, são abordagens muito distintas e isso se observa desde a formação do objeto científico de pesquisa: o poder, para a Ciência Política; o próprio Poder Político (Estado), para a Teoria Geral do Estado.

No início, o Estado como sociedade política organizada é visto como indutor do direito; em meados do século XX, com Kelsen (1998), o Estado é equiparado ao direito. Por fim, especialmente no pós-Segunda Grande Guerra, a tese de que o direito deve regular o Estado - limitar o poder - ganha muita força, inclusive com amplo reflexo no direito internacional, com a criação do ONU (1946) e a proclamação da Declaração dos Direitos Humanos, em 1948. Por esta construção teórica e conceitual que vem se afirmando há meio século podemos compreender as primeiras noções acerca do aparelho estatal:

- Historicamente, o Estado manifesta continuamente duas de suas atividades ou características mais atuantes: ora se presta à dominação ora se volta à opressão.

- Estado é uma organização institucional específica que sistematizou, centralizou o Poder Político.

- O Estado é a instituição mais forte (status) que preside a organização social.

Além dessas características, ainda podemos dizer que o Estado:

- Exerce o monopólio do uso legítimo da força física;

- Está baseado no centralismo e no monismo jurídico (monopólio da produção legislativa);

- É a instituição política por excelência. 
De modo simplificado, para muitos, o Estado se limita à União, uma vez que só a União tem soberania - os demais entes da Federação teriam apenas uma autonomia limitada e residual: o que não interessa à União compete ao Estado-membro e assim, sucessivamente, ao Município. Esta é uma confusão entre a concepção de Estado e organização políticoadministrativa do Estado: a título de exemplo, o federalismo brasileiro compreende quatro entes políticos (União, Estados, Distrito Federal e Municípios), todavia, a soberania é uma atribuição da República Federativa do Brasil, posto que, a soberania age no interesse nacional, representando a nação brasileira em aspecto externo; já a União, enquanto ente político, age no interesse federal, em um aspecto interno, com a sobreposição da burocracia sobre a política.

Para Deleuze (1995): O Estado é a soberania. Entretanto, a observação de que o Estado - além de ser uma instância privilegiada de poder - deve ser estudado como artefato científico foi entrelaçada por Jellinek.

\subsection{A Teoria do Estado em Georg Jellinek}

Além de um teórico precursor do Estado, Georg Jellinek (2000) foi um jurista alemão e filósofo do direito. É reconhecido como o fundador da disciplina de Teoria Geral do Estado, pois até sua obra ser conhecida aplicava-se uma leitura ora idealista (Filosofia do Estado de Hegel, por exemplo) ora negativista (ideologias do Estado, no exemplo da tradição marxista). Sua maior contribuição está, portanto, na tentativa de se realçar as bases de uma disciplina ou ciência que verificasse elementos de formação e de continuidade das estruturas e dos mecanismos do aparato estatal. A partir de sua obra mais específica sobre Teoria Geral do Estado, os elementos políticos de composição do Poder Político, que se sagraram historicamente, passaram a ser investigados quando se analisa o fenômeno estatal: povo; território; soberania. Exatamente nesta ordem e sequência lógica.

É preciso ressaltar, neste momento, que o Estado centraliza o Poder Político, mas há outras instituições e comunidades políticas que conformam o Poder Político. A Multidão (HARDT; NEGRI, 2005), atualmente, seria um desses agrupamentos com caráter político, além das associações políticas que lutam pelo controle do Estado ou, ao contrário, os 
primeiros grupos humanos que detinham o controle social sobre o Poder Político - antes, portanto, da fundação do próprio Estado.

Ainda é preciso lembrar que, para o jurista alemão, a soberania recai sobre o Estado e não exatamente sobre a nação. Bonavides (2012, p. 71) traz a definição que Jellinek atribui ao Estado, como "a corporação de um povo, assentada num determinado território e dotada de um poder originário de mando".

Para Dallari (2000, p. 118), comparativamente, Estado é "a ordem jurídica soberana que tem por fim o bem comum de um povo situado em determinado território". Não só a soberania pertence à nação, para o jurista brasileiro, como a nação é sinônimo de povo, resguardado pela ordem jurídica legítima (bem comum). Para o jurista brasileiro é impossível não tratar do Bem Comum, uma vez que não se imagina racionalmente que o Estado se ampare na Constituição Federal para perpetrar o mal social, intencionalmente, ao povo. Ainda se deve compreender que, do ponto de vista jurídico, suportado por princípios como igualdade, isonomia, equidade, moralidade, dignidade, não há classes sociais de indivíduos desconexos (segurança jurídica) e, se houver - por qualquer razão - discriminação e desigualdade, estas deverão ser corrigidas pela aplicação do discrímen (MELLO, 2005). O que se confirma na definição institucional do Estado, como centralização legal e legítima do Poder Político (MARTINEZ, 2015) ${ }^{10}$.

Por sua vez, na entrada do século XXI, como ensina Häberle (2008b), já era preciso ler a Constituição e o Direito como fomento cultural. Assim, pode-se ter o pluralismo como uma ideia luminar e a cultura como um conceito aberto. No caso brasileiro, teríamos de ver como se arranjaram reciprocidade e multiculturalismo na ordem jurídica ou, em outras palavras, cidadania e garantias constitucionais. Este marco analítico constituiria um verdadeiro pluralismo constitucional: a cultura na Constituição. Também seria terreno fértil à elaboração teórica e prática do que se convencionou chamar de Estado Social na Sociedade Aberta.

Este conjunto de defesas constitucionais alicerçado pela ordem da cultura ainda serviria ao combate das formas fascistas e totalitárias de Estado que se tem anunciado. Portanto, Häberle (2008b) intenta constituir um modelo jusfilosófico (axiológico) da cultura,

\footnotetext{
${ }^{10}$ Todo discurso sobre o direito parte da ideia de Estado ou a postula, pois ele é, ao mesmo tempo, autor e sujeito do direito, e o conjunto das disciplinas jurídicas o vê como instituição maior [...] Isso significa que o Estado pode ser abordado de duas maneiras distintas, mas complementares, segundo seja visto como um fenômeno histórico e social de regulação dos comportamentos, ou segundo seja apreendido como uma instituição jurídica (ALLAND; RIALS, 2012, p. 702).
} 
notadamente nas sociedades modernas altamente racionalizadas. Evidentemente que sob um escrupuloso respeito à diversidade cultural - seria como um ideário a constituir uma sociedade multicultural e multiétnica.

\section{O Estado no mundo pós-moderno}

Do passado clássico ao presente incerto, experimentamos o declínio do Ocidente como direção acertada (e desfeita) de um processo civilizatório copiado da Modernidade Tardia e de sua teleologia. Não há mais racionalidade presumível e nem perfectibilidade como apostas certas no futuro líquido e certo - essas rubricas são sérias baixas para a modernidade que, tardiamente, responde com a força (Razão de Estado e exceção).

O resultado, na ponta final, é o ser humano que se perde como valor básico. Ironicamente, a Razão de Estado (RE) é conclamada como universo do poder e a exceção, universalmente, de conceito e possibilidade jurídica passa a ser hegemônica no realismo político. A Razão de Estado (RE) é cada vez mais a razão de existir dos poderes excepcionais e excludentes; pois, como excedentes públicos são apropriados pelo Poder Político.

O problema do "ser" retorna nos problemas existenciais (e materiais) da Modernidade Tardia (VATTIMO, 2003, p. 55). Não se evitou a guerra de culturas, não por falta de racionalidade, mas sim por se utilizar exatamente a mesma fonte de razão (econômica, cultural e científica) dentro e fora do Ocidente. Desse modo, ninguém se interessa pela paternidade (filosófica e política) da exceção, pois todos a empregam livremente em todos os quadrantes da nacionalidade defendida. Esta secularização (e racionalização extrema quanto aos fins: custo/benefício) é tão consumada quanto consome o Ocidente ${ }^{11}$ - e esta é outra pista para se ver como o modelo analítico do tipo ideal (racional) do poder pode gestar a exceção.

Em outras palavras, a exceção é o produto final da racionalidade política da Modernidade Tardia. Chegando-se ao ápice (e consumindo-se), Ocidente, Estado, Direito, Racionalidade, fariam de tudo para se preservar (RE) e com o emprego de todas as forças (i)legítimas - lembremo-nos de que a exceção é legitimada. Afinal, “os fins (o poder do Ocidente) justificam os meios (exceção)".

\footnotetext{
${ }^{11}$ Esse é o sentido mais importante e radical da descoberta de Max Weber [...] O Ocidente, pode-se dizer, declina, porque declinar constitui a sua vocação histórica. Em outras palavras, a história, no único modo que o Ocidente consegue concebê-la e vivê-la, é a história da secularização (VATTIMO, 2003, p. 57).
} 
O discurso das bases e da fundação (o Destino Manifesto que cabe na RE tardia) é, em outra dimensão, colocado à frente das práticas funcionais do poder. A exceção é a peça que faltava no funcionalismo da coerção que serve de estrutura ao Estado ocidental. Desse ponto de vista não há crise da razão política, mas estiramento de suas consequências na Modernidade Tardia.

Neste ponto, revelou-se claro o processo de secularização: trocamos de lugar a razão antes aposta na RE, pela exceção. Passamos da ultima ratio para a prima ratio. Portanto, infelizmente - tanto para a Filosofia do Declínio quanto para o mundo da vida -, não há declínio da violência em favor de uma "adesão a modelos científicos de sociedade" (VATTIMO, 2003, p. 61). O que parece restar bem sólida é a racionalidade do Poder Político.

Em suma, a ultima ratio (RE) configura-se em primeira instância de poder $^{12}$; porém, ocorre que a prima ratio é a exceção. Ou seja, RE e exceção transparecem lúcidas e fundidas: como meio e fim de um só. Assim, não há declínio ocidental, mas superfaturamento do poder na Modernidade Tardia. No Ocidente e no Oriente vemos vítimas da racionalidade que produziu a Razão de Estado e seu exceptio. Na soberania de conquista da Modernidade Tardia, fins e meios, RE e exceção, formam um bloco monolítico do "novo" Estado Absolutista.

Nesse aspecto, a sociedade capitalista ${ }^{13} \mathrm{e}$, principalmente, o Estado, são obras modernas $^{14}$. De qualquer forma, hoje, como no passado, o Estado é provocador com sua morosidade, demorando, inclusive, para desmoronar sob o pós-moderno. O Estado, entretanto, é uma obra perfeitamente moderna - e é uma obra inacabada seguindo as formas da Sagrada Família.

As queixas a serem feitas, portanto, não são de que as promessas do Estado não foram cumpridas, mas de que o próprio Estado Moderno foi a principal promessa do Renascimento $^{15}$, assim como a modernidade - se bem que essa é aguardada até hoje para ser

\footnotetext{
12 http://oapolitico.blogspot.com.br/2007/02/raison-dtat-em-maquiavel-e-spinoza.html.

${ }^{13}$ Ironicamente, mesmo na ampla parcela de Brasil atrasado, o Estado de Direito meio-colonialista é moderno. Principalmente se for lembrado que apenas o projeto do Iluminismo era agregador e que o modelo econômico brasileiro soube articular a escravidão com o capitalismo (já monopolista).

14 No mais, cabe lembrar que o individualismo sempre foi um tópico marcante da modernidade, como característica básica da Renascença. Como exemplo, destaca-se que os banqueiros têm lugar cativo no Inferno de Dante (ALIGUIERI, 1998).

${ }^{15}$ São elementos de destaque desse período: Antropocentrismo, Humanismo, Racionalismo e o respeito à individualidade.
} 
uma realidade. Assim, além de não terem sido ultrapassadas suas barreiras, a modernidade sequer é uma realidade para pelo menos dois terços da Humanidade ${ }^{16}$.

Se o Estado Moderno foi pautado pela estabilidade e segurança de suas instituições desde a Paz de Vestefália, em 1648, o chamado Estado Pós-Moderno (CHEVALLIER, 2009) enfrenta a falibilidade e a incerteza de que suas amarrações e institutos são aplicáveis e efetivos. Se forem observados mais atentamente, notar-se-á que a crise de legitimidade do Poder Político centralizado decorre, no mínimo, da década de 1970 (LYOTARD, 1989).

As sociedades complexas procuram por autonomia fora do controle estatal. Para o Estado Moderno, autonomia sem soberania é sedição, ou seja, o mais grave dos crimes políticos. A própria dinâmica do capital financeiro, fugaz, insólito, movediço, não pode esperar pela solução dos entraves burocráticos.

A notável lentidão, sedimentação dos assuntos de Estado foram desafiadas por uma inigualável velocidade política (VIRILIO, 1996). O Estado não fora inventado para agir com celeridade - haja vista a profundeza das raízes de suas tradições. Esta é uma das contradições já vistas, mas há outras entre o discurso racional do Estado de Direito e a ação pragmática e instrumental do mundo pós-moderno. Resta saber, portanto, como sociedades orientadas pela instabilidade (como a brasileira) serão administradas pelas rotinas políticas da incerteza.

O Estado habituado a ordenar as relações sociais por meio de pactos federativos, bastante estáveis e em que as competências são definidas anteriormente e com clareza, a partir de então, passou a enfrentar o desafio da inconstância. A modernidade cultivou a esperança do amanhã, inclusive transportando os repertórios do presente. A crise retirou, sobretudo, esta capacidade teleológica da inventividade social humana.

O mundo midiático já se pronunciava profundamente modificado na década de 1950, pois se supunha uma relação diferenciada para o Poder Político, com a chegada da TV (MACLUHAN, 2005). O mesmo teria ocorrido com a invenção da prensa (e da imprensa), por Gutemberg, no Renascimento, e cinco séculos depois, com as redes da telemática, da internet e dos celulares, já no final do século XX - período que Santos (2012, p. 177) denomina "sistema. técnico atual".

\footnotetext{
${ }^{16}$ Enfim, qual é a dimensão do Brasil, por exemplo, que sequer conhece a modernidade? Não é à toa que só aportou por aqui em 1920. Aliás, tanto é assim que a maioria do povo, caso fosse consultada, sequer saberia informar que houve uma "Semana de Arte Moderna".
} 
Porém, no século $\mathrm{XX}$, antecipada pela indústria da propaganda nazista, a política se revelaria definitivamente como palco do marketing e da produção da imagem, como reflexo da opinião pública fabricada e não como conteúdo. Sem conteúdo ou com conteúdo corrigido pelo departamento financeiro (dos anunciantes), a relação com o poder viria com a imagem e depois com a fractalidade (LÉVY, 1996.).

Por esse fenômeno, não haveria mais unidade de referência do poder: os segredos de Estado seriam devassados continuamente, especialmente com a era da Internet e das tecnologias em rede. O escândalo de espionagem das comunicações institucionais do Brasil, pelas agências de segurança dos EUA nos últimos anos, é apenas um indício da vulnerabilidade digital que se apresenta ${ }^{17}$.

Por seu turno, o Estado Sedutor (seduzindo) anteciparia a relação pós-moderna com a política (DEBRAY, 1993), com o discurso programado do teleprompter, da imagem pública enfeixada em megapixels, com a razão imagética ${ }^{18}$ conduzindo as consciências. A verdade republicana, primeiro, seria colonizada pelo tubo catódico do maniqueísmo preto e branco; até que dialética fosse substituída pela ditadura das imagens e das cores que viriam nos anos seguintes.

A partir da década de 1970, com os experimentos econômicos do neoliberalismo e da globalização, O Estado enfrentaria outros desafios às tradicionais estruturas políticas, especialmente na soberania. Além da rivalidade do Poder Econômico policêntrico, em que os recursos do capital volátil tendem à concentração nas áreas de maior segurança e rentabilidade, o Estado nacional ainda enfrentaria a necessidade (imposta constitucionalmente) da distribuição das compensações sociais, revelando-se uma pulverização das políticas públicas ${ }^{19}$.

Ante a proposição absolutista de se centralizar as decisões no poder central, como diz Canotilho, a autonomia seria cada vez mais requerida, como reserva normativa da

\footnotetext{
${ }^{17}$ Nesse sentido, a Organização das Nações Unidas (ONU) recepcionou indicação do Brasil e da Alemanha para a expedição de resolução reprovando as condutas governamentais invasivas do espaço virtual e das comunicações em geral.

${ }_{18}^{18}$ Parafraseando o pensamento jurídico, o que não está nas ondas das imagens catódicas não está no mundo.

${ }^{19}$ Bem como precisaria "administrar as situações coletivamente perigosas". O Estado seria responsabilizado por suas ações, mas, via de regra, quem pagaria seria o povo, quando em seu nome ouviria que sua liberdade fora retirada para se pacientar sua segurança (nacional).
} 
sociedade civil (CANOTILHO, 2006): outro ponto de fuga, certamente, para a centralização da soberania do Estado Moderno clássico.

Todavia, outras mutilações constitucionais iriam convergir com a mondialisation fractale $^{20}$, mitigando-se o monopólio estatal da atividade legislativa e do controle do uso da coerção. Fora isso, a fragilidade institucional recebeu acréscimos da fragmentação da ação política estatal - politics - em múltiplas políticas públicas: policies (SOARES, 2011).

De forma geral, esses e os demais dados colecionados - em conjunto - expressariam reflexos tardios da modernidade (ao invés de sua pós-modernidade). Mesmo a telemática seria um desdobramento instrumental, um recorte, um novo aporte ou suporte da tecnologia aplicada à comunicação. Este fluxo que se iniciara precisamente com Gutemberg (GIDDENS, 1991).

\section{O Direito no mundo líquido}

Sobre a condição imperiosa das tecnologias digitais - sejam já derivadas da Inteligência Artificial (ou não) -, a realidade societal se vê refém do inusitado e incompreensível muitas vezes para os sentidos de especialistas. No tocante às tradições do Estado de Direito, basta-nos pensar que a realidade virtual - dos crimes cibernéticos e das criptomoedas - desconhece qualquer pretensão de limites.

Então, começando pelo Princípio da Soberania, todos os demais princípios gerais do direito passariam por profunda modificação. Experiências judiciais próprias da descentralização, como a mediação, negociação e arbitragem são frutos do século $\mathrm{XX}$ e podem seguir em tela no futuro-presente. Porém, pode ser que o lado estranhado (não assimilável à vida social) das tecnologias venha a se sobrepor. Assim, no tocante à evolução destas últimas, caracterizada por um fluxo contínuo que inutiliza versões anteriores em uma velocidade quase descontrolada, como saber sua definição no futuro, e que direitos exigirá para uma existência pacífica e ética com a sociedade humana?

Juridicamente, sob a hipótese (real) de a Inteligência Artificial emitir sentenças - a exemplo do que as consultorias advocatícias que já conferem - o que seria do Princípio do Juiz Natural? A quem culpabilizar se uma dessas decisões incidir contra os direitos humanos

\footnotetext{
${ }^{20}$ Como se vê na expressão francesa, o fractal é aqui empregado no sentido de uma profunda artificialidade.
} 
- impactando fortemente a sociedade internacional? Pode soar meio absurdo, neste exato momento, mas se já é fato que a técnica se movimenta em razão distinta da Ética, que patamar de eticidade - vale dizer, de processo civilizatório - será razoável (racional) ao futuro do Estado de Direito?

A Inteligência Artificial, como todo suporte de gestão de informações, será eleita (por quem?) para superar o Princípio da Representação Popular? Se esta modalidade de inteligência, criada artificialmente por nós humanos, já se notabiliza por ser mais inteligente do que a espécie criadora, o que será feito do Princípio da Iniciativa?

É óbvio que a Ágora, a Polis, a cidadania ativa que recobre a democracia direta sofrerão com isto - e esse curso será bom ou mal? Terá algum significado a liberdade de expressão, para falarmos mal e reclamarmos da total ingerência da IA na vida política? Como distinguir o Totalitarismo Econômico atual - com base no capital financeiro - de um Totalitarismo Cibernético? E, em o fazendo com alguma clareza de distinção, a quem reclamar, contra quem ou com o que lutar?

Institutos como recall, impeachment, accountability, referendos e plebiscitos (além de iniciativa popular), desobediência civil não parecem muito adequados. Então, o próprio Direito de Petição - apregoado na Carta Magna, de 1215 -, como direito de se insurgir contra a execução das políticas administrativas também estará descartado (MARTINEZ, 2018b).

\section{Teorias do Estado sob o golpe constitucional}

Neste último item, traremos alguns aportes previamente sugeridos/analisados para o cenário nacional inscrito no pós-2016. Assim, pode-se dizer que vivemos, inequivocamente, sob um "novo" tipo de Estado de Exceção - não se trata mais daquele recurso interposto constitucionalmente no pós-Revolução Francesa (AGAMBEN, 2004), mas de algo muito mais sofisticado diante das oportunidades institucionais e tecnológicas trazidas ao longo do século XXI. O país, refém do ideário involutivo dos direitos fundamentais, na construção de um real e impiedoso antidireito (FILHO, 2002), vive "nova" hermenêutica em que vigora a força normativa do realismo político. A Constituição, abarcada pelos três poderes, não faz sombra ao processo que se iniciou com a Assembleia Nacional Constituinte em 1985. Por 
isso, hoje, em 2017, não se vive um “acréscimo mental” - tampouco há "concentrado na Constituição" (HÄBERLE, 2016, p. 23-24).

O país é gerido por forças de nato-fascismo ${ }^{21}$ e tem a seu dispor todos os recursos plausíveis interpostos pelo regime de exceção em forma de cesarismo regressivo (Gramsci: 2000): Cesarismo de Estado. Uma das facetas do que aqui se denomina de Cesarismo de Estado é a articulação dos três poderes - em real forma de Estado de Exceção - que desnutre a República e o Princípio Democrático. Faz-se uso da legalidade (seletiva) ou da ilegitimidade, da letalidade da força policial (como $\underline{\text { Bonapartismo Policial }}^{22}$ ) no intuito de criminalizar os movimentos sociais, sob o comando da cúpula dos três poderes. Não há limites para Bonaparte (MARX, 1978).

Sem as lições preciosas da história e uma reflexão apurada sobre a conjuntura, o fascismo prospera no Estado e nas catedrais brasileiras: gays são perseguidos nas ruas e nas suas casas, em qualquer grande centro urbano - no interior, onde todos se conhecem, o anonimato protege menos os agressores. Num caso típico de Bonapartismo Policial, dois idosos foram agredidos por moradores de seu condomínio e, ao prestar queixa, saíram como autores da agressão: sequer realizaram exames de corpo de delito ${ }^{23}$.

Do mesmo modo, sob a ação (ou inação calculada) do Bonapartismo Policial, negros, brancos pobres e trabalhadores rurais e urbanos são acossados pelas forças policiais de repressão e pelos aparatos judiciais de Estado. Quilombolas e povos indígenas são assassinados aos olhos complacentes do Estado e de suas polícias que, em tese, estariam posicionadas ali para evitar ou conter a violência desenfreada.

Pode-se dizer que esta seja a ponta de lança armada do capital no miolo do Estado nato-fascista que se constrói no Brasil, desde 2016. O avanço do fascismo em nosso país pode ser replicado em duas dimensões: 1) Nato-fascismo enquanto "natural" (esperado, programado para assim ser), uma vez que as graves contradições sociais herdadas da colonização escravista e estimuladas pela intensa guerra civil (capitalismo predatório) têm como resposta uma repressão urbana e rural sem fim; 2) É um tipo de nato-fascismo enquanto aguarda ordens superiores (aos moldes de 1964) do Império do Norte, atendendo sua força

\footnotetext{
${ }^{21} \mathrm{http}: / /$ www.gentedeopiniao.com.br/noticia/tiradentes-esta-em-curitiba-por-vinicios-martinez/ 165176.

${ }^{22}$ Toma-se aqui, de empréstimo, o consagrado termo cunhado por Marx (1978) para se referir a Luís Bonaparte, ao fazer uso de todos os meios possíveis a fim de debelar a consagração do poder popular.

${ }^{23}$ Disponível em: <https://br.blastingnews.com/sociedade-opiniao/2017/05/casal-de-idosos-gay-e-espancado-norio-de-janeiro-001665485.html> Acesso em: 14 mai. 2018.
} 
bélica e econômica colonizadora e devastadora: a entrega do petróleo nacional, especialmente o Pré-Sal sem controle algum sobre os lucros dos investimentos multinacionais, é só um presságio.

Este conjunto e muitos outros fatores, como o Cesarismo de Estado, em que a tripartição de poderes é aniquilada por um triunvirato acomodado nos privilégios de castas na cúpula dos três poderes ${ }^{24}$ - na sequência à Ditadura Inconstitucional de 2016 (MARTINEZ, 2017) -, lembram com sobras o conceito de Bonapartismo, de Marx (1978), e a interpretação que lhe dá Losurdo (2004), com destaque notável à ausência de qualquer meio regulador dos três poderes: na conta do Federalista.

A Ditadura Inconstitucional tem por base uma situação de fato que é quase invisível a olho nu, mas, por meio de um brevíssimo resgate, considerando aspectos importantes, é possível inferir que, quando buscadas microrreferências, a própria tipologia da ditadura não possui um fim. Bem por isso, podem-se destacar, ao menos, quatro formas básicas que teriam originado outras inúmeras modificações/adaptações ao longo da história política: (i) Roma antiga - para o dictator, havia expedição de poder suplementar por iniciativa do Senado Romano - com prazo específico para abdicação do posto de César - e com a finalidade específica de conter e solucionar graves problemas sociais, como uma guerra civil, um caso clássico é o de Caio Júlio César; (ii) Ditadura Absolutista Inconstitucional - por certo, é uma ditadura inconstitucional, pois o mandatário que (re)toma o poder, via de regra, assim o faz em total desconsideração aos mandamentos constitucionais, nesse caso, poder ex parte principis é absoluto, incondicionado a qualquer preceito legal que não seja a vontade do soberano. Por isso, se a Constituição é uma “embalagem de lixo sem serventia”, sob a ação de notório(s) abusador(es) do poder e do direito, talvez o mais correto fosse denominá-la como ditadura absolutista inconstitucional, uma vez que o poder de exceção atua sem limites, assim como a soberania que não requisita superlativos. Exemplos: Idi Amin Dada (Uganda), Papa Doc e a milícia Tonton Macoute, no Haiti; (iii) Ditadura Constitucional - o jurista alemão Carl Schmitt, na base do direito nazista, é enfático ao destacar que a própria Constituição contém regras de exceção que suspendem as normas vigentes. A previsão do Estado de Sítio suspendendo direitos fundamentais - é um caso clássico. O que a diferencia do segundo caso

\footnotetext{
24 Disponível em: <http://www.gentedeopiniao.com/noticia/revolucao-burguesa-por-vinicio-martinez/165134> Acesso em: 14 mai. 2018.
} 
e a aproxima do primeiro, aqui denominados, é a convenção acerca de um poder de exceção com previsão legal -, de que deriva um mandato delegado e não outorgado, como no caso da ditadura absolutista inconstitucional. Portanto, traz elementos que a aproximam da tipologia romana e, um pouco, da nossa atualidade em 2016; (iv) Ditadura Inconstitucional - trata-se do modelo típico de dominação racional-legal (Estado de Direito de Exceção), ocorrido em 2016, mas, diferencia-se do segundo tipo (Absolutismo Ilegal), porque não há desconsideração constitucional absoluta. Não há mutação constitucional que não passe pelo legislativo, bem como há interpretações judiciais da Carta Magna que permitem - sem (re)fundar uma Hermenêutica Constitucional, por completo - violar frontalmente direitos fundamentais. Além disso, há manipulação da $\mathrm{CF} / 88$, como na própria sentença do Impeachment, que produz o antidireito; como ideologia jurídica constitucional (a Treva Branca) produz um embate direto à Constituição. O papel do Judiciário e das polícias (como reserva das forças armadas) é essencial. Não se recorre ao manu militari porque as polícias cumprem sua missão constitucional, e os tribunais que validam violações de direitos fundamentais são, concretamente, Tribunais de Exceção. Por fim, interpretações inconstitucionais da $\mathrm{CF} / 88$ permitem que "certos" princípios sejam vergados contra a própria Constituição (MARTINEZ, 2017).

De empréstimo do conceito, no tocante ao uso socialmente repressivo de forças policiais regulares e que, teoricamente, deveriam seguir "o estrito cumprimento do dever legal" - sendo desnecessário até o momento o emprego de contingentes das três Forças Armadas -, vislumbramos como se modula o Bonapartismo Policial.

No nosso caso, como para agravar o status ilegítimo de quem usa as forças policiais em defesa do capital e contra a sociedade, em desfavor do povo, grupos sociais indefesos ou movimentos sociais de resistência ao fascismo e ao desmonte dos direitos fundamentais constitucionais, recordemos que as forças policiais são uma reserva das Forças Amadas. Assim consideradas por dispositivo constitucional sobrevivente do regime militar de 1964 (art. 144, § $6^{\circ} \mathrm{da} \mathrm{CF} / 88$ ).

A fim de que não se confundam as coordenadas de Golpe de Estado perpetradas no país em 2016, com o próprio Golpe Militar de 1964, tomemos o exemplo do Uruguai, especialmente a partir de 1972: 
Com a chegada à presidência de Jorge Pacheco Areco, em dezembro de 1967, iniciou-se um crescente autoritarismo no Uruguai, com a utilização constante de medidas de exceção, técnicas repressivas e violência política. Durante o período da escalada autoritária neste país - que se estende até o golpe de Estado, em 1973 -, começaram a se manifestar os elementos que posteriormente seriam utilizados pela ditadura, e que a caracterizam como um regime baseado na promoção do Terrorismo de Estado. Isso faz com que o período autoritário que se iniciou com Pacheco Areco e continuou durante o governo do presidente golpista, Juan María Bordaberry, seja denominado como o do "golpe de Estado mais longo", "golpe em câmara lenta", "governo semi-ditatorial" ou, ainda, de "ditadura constitucional" (JELLINEK; LEDESMA, 1980) (PADRÓS; FERNANDES, 2018- grifo nosso)

Em resumo, basta ter em consideração que o gás lacrimogêneo, utilizado contra o povo que se rebela em defesa da democracia e dos direitos fundamentais, é terminantemente proibido em cenários de guerra ${ }^{25}$.

\section{Considerações Finais}

A Razão de Estado cedeu lugar à Razão de Exceção na modernidade tardia, abandonando as saídas radicais que têm capacidade de retomada de consciência e de poder ao povo. Os efeitos do direito líquido, ao mesmo tempo que interferem beneficamente com a introdução de mecanismos de participação democrática e ampliam o espaço público, trazem consigo dificuldade na identificação dos sujeitos, sobretudo que atuam em nome do Estado.

No caso do Brasil, o colonialismo é reincidente. No momento presente, julga-se ter o completo domínio das ações e das consequências. Contudo - ou principalmente - por não haver projeto de futuro, o brasileiro é marcado por limites: o novo depende, sobretudo, da insatisfação com o atual. A novidade depende do que há à disposição desse contingente na atualidade.

Essa interseção entre o passado e o futuro, mesmo que não projetado, delimita o acerto de contas que ainda não foi fechado com a modernidade. Por isso, modernitas quae sera tamen $^{26}$. Esse retrato, por sua vez, tem início em 2016, com a instauração da Ditadura Inconstitucional. A chegada do modelo de Estado contemporâneo ao Brasil inaugura-se com a legalidade ilegítima, a utilização da exceção como forma de governo, sob as bases das inspirações totalitárias como Agamben (2004) aponta. É um meio eficaz de confundir burocracia e política, interesse público e privado, tornando indistinguível, ainda, as próprias

25 Disponível em: <http://www1.folha.uol.com.br/mundo/2017/05/1880115-por-que-o-gas-lacrimogeneo-eusado-em-protestos-mas-proibido-na-guerra.shtml> Acesso em: 15 mai. 2018.

${ }^{26}$ Em latim, "faça-se a modernidade ainda que tardiamente" ou "modernidade ainda que tardia". 
funções executiva, legislativa e judiciária. Nesta medida, a Constituição perde sua característica de instrumento de contínua realização da vontade popular.

O novo desenho de Estado sobrepõe soberania e território - com conflitos internos resolvidos a toque de exceção, como a intervenção federal - em detrimento do povo, antes um elemento conditio sine quo non, contrariando os postulados humanitários e caindo em regressão cesarista.

No entanto, trata-se de uma fórmula que vem se aprimorando na América Latina: Venezuela $(2002)^{27}$, Bolívia $(2008)^{28}$, Honduras $(2009)^{29}$, Equador $(2010)^{30}$ e Paraguai $(2012)^{31}$. Sob essa demarcação da política e da economia nacional, arcaica ou modernizada, a estrutura corporativa que se apodera do Estado - como se fosse patrimônio pessoal - alimenta a privatização do Poder Público, bem como dissemina a corrupção nas várias dimensões societais sob seu controle e domínio. O que remete à atualidade de uma questão básica: a legitimidade.

\section{Referências}

AGAMBEN, Giorgio. Estado de Exceção. São Paulo : Boitempo, 2004.

ALLAND, Denis; RIALS, Stéphane. Dicionário da Cultura Jurídica. São Paulo: Martins Fontes, 2012.

BASTOS, Celso Ribeiro. Dicionário de Direito Constitucional. São Paulo : Saraiva, 1994.

BONAVIDES, Paulo. Ciência Política. São Paulo : Malheiros, 2012.

\footnotetext{
${ }^{27}$ Em tentativa de desmoralizar o governo de Hugo Chávez, opositores caminharam em protestos, assim como defensores, e, em seguida, franco-atiradores dispararam na cabeça dos manifestantes indistintamente. Na rede de TV comandada pela oposição, um grupo de militares já se pronunciava dizendo não mais reconhecer o poder estabelecido. O Parlamento seria fechado pela oposição.

${ }^{28}$ Grupos opositores ao presidente Evo Morales tomaram à força várias instituições públicas, na tentativa de operacionalizar um levante global ou "golpe civil".

${ }^{29}$ Em 2009, Manuel Zelaya foi deposto em golpe cívico-militar. Em 2010, como prenúncio do bonapartismo policial, a campanha presidencial seguinte foi centrada no combate à criminalidade. $O$ golpe, por sua vez, seria condenado pela Assembleia Geral das Nações Unidas (ONU), ao desabonar a prisão de Zelaya pelo exército, cumprindo decisão judicial.

${ }^{30} \mathrm{O}$ presidente Rafael Correa foi sequestrado e esteve mantido em cárcere privado por cerca de 13 horas, quando forças policiais descontentes com a Lei de Serviço Público implementaram uma espécie de bonapartismo policial: forças públicas usam de violência brutal, ao arrepio da lei, para atemorizar um corpo político, parte da sociedade ou grupos sociais de oposição a seus interesses.

${ }^{31}$ O impeachment do presidente Fernando Lugo, apelidado de "golpe relâmpago", foi aprovado pelo Senado paraguaio em pouco mais de 24 horas. $\mathrm{O}$ ato foi considerado golpe, "violação da ordem democrática", pela União das Nações Sul-Americanas (Unasul).
} 
CANOTILHO, J. J. G. Estado de Direito. Lisboa: Gradiva, 1999.

CHEVAlLIER, J. O Estado Pós-Moderno. Belo Horizonte: Fórum, 2009.

COTARELO, Ramón. Teoría del Estado. IN : DÍAZ, Elías; MIGUEL, Alfonso Ruiz.

Filosofía política II - Teoria Del Estado. Madrid : Editorial Trotta, 2014.

DALLARI, Dalmo de Abreu. Elementos de Teoria Geral do Estado. $21^{\text {a }}$ ed. São Paulo : Saraiva, 2000.

DANTE ALIGUIERI. A Divina Comédia - Inferno. São Paulo : Editora 34, 1998.

DEBRAY, R. O Estado Sedutor: as revoluções midiológicas do poder. Petrópolis: Vozes, 1993.

DELEUZE, Gilles; GUATARRI, Félix. Mil Platôs: capitalismo e esquizofrenia. Vol. I e V. Rio de Janeiro: Editora 34, 1995.

DELEUZE, Gilles. Conversações, 1972-1990. Rio de Janeiro : Ed. 34, 1992.

GIDDENS, A. As consequências da modernidade. São Paulo: UNESP, 1991.

GRAMSCI, Antonio. Cadernos do Cárcere. (Org. Carlos Nelson Coutinho). Volume III.

Nicolau Maquiavel II. Rio de Janeiro : Civilização Brasileira, 2000.

HÄBERLE, Peter. EI Estado Constitucional. México \& Peru : Tarea Associación Gráfica Educativa, 2003.

HÄBERLE, Peter. Pluralismo y Constitución: estudios de teoría constitucional de la sociedad abierta. Madrid: Tecnos, $2008 \mathrm{~b}$.

HARDT, Michael; NEGRI, Antonio. Multidão: guerra e democracia na era do império. São Paulo: Record, 2005.

HEGEL, G. W. F. Princípios da Filosofia do Direito. São Paulo : Martins Fontes, 1997. HOBBES, Thomas. Leviatã. Col. Os Pensadores. $3^{\text {a }}$ ed. São Paulo : Abril Cultural, 1983. IANNI, Octavio. Revolução e cultura. Rio de Janeiro : Civilização Brasileira, 1983. 
IANNI, Octavio.Tipos e mitos do pensamento brasileiro. Sociologias, [s.1.], n. 7, p.176-187, jun. 2002. FapUNIFESP (SciELO). Disponível em:

<http://www.scielo.br/pdf/soc/n7/a08n7.pdf>. Acesso em: 14 mai. 2018.

JELLINEK, Georg. Teoría General del Estado. México : Fondo de Cultura Económica, 2000 .

KELSEN, Hans. Teoria Geral do Direito e do Estado. $3^{\text {a }}$ ed. São Paulo : Martins Fontes, 1998.

LÉVY, P. O que é o virtual? São Paulo: 34, 1996.

LYOTARD, J-F. A condição pós-moderna. Lisboa: Gradiva, 1989.

MACLUHAN, M. Macluhan por Macluhan: conferências e entrevistas. Rio de Janeiro, Ediouro, 2005.

MARTINEZ, Vinício Carrilho. Teorias do Estado: instituições e dilemas do Estado de Direito Capitalista. São Paulo : Scortecci, 2012.

MARTINEZ, Vinício Carrilho. Teorias do Estado - Estado de não-Direito: quando há negação da Justiça Social, da democracia popular, dos direitos humanos. São Paulo : Scortecci, 2014.

MARTINEZ, Vinício Carrilho. A Teoria do Estado entre os séculos XIX-XXI: do Estado ético-racional (Hegel e Weber) ao Estado de Exceção. São Paulo : Scortecci, 2015.

MARTINEZ, Vinício Carrilho. Teoria Geral do Estado de Direito de Exceção. Pesquisa de Pós-Doutorado em Ciências Políticas. UNESP/Marília, SP: [s.n.], 2017.

MARTINEZ, Vinício Carrilho. Tipologia das Ditaduras. 2017. Disponível em:

<https://www.gentedeopiniao.com.br/colunista/vinicio-carrilho/tipologia-das-ditaduras>. Acesso em: 14 mai. 2018.

MARTINEZ, Vinício Carrilho. Direito Líquido: o poder ex parte princips. IN : SALETE, Roseli (et. al.). Direitos Humanos e Criminalidade. Paraná/Brasil, Grafibem, 2018a.

MARTINEZ, Vinício Carrilho. JANJÁCOMO, Caroline; SCHERCH, Vinícius Alves. Direito líquido. Em tempos rarefeitos, o direito é líquido. Revista Jus Navigandi, ISSN 1518-4862, 
Teresina, ano 23, n. 5350, 23 fev. 2018. Disponível em: <https://jus.com.br/artigos/64108>. Acesso em: 14 maio 2018b.

MARX, Karl. O 18 Brumário e cartas a Kugelmann. 4ª ed. Rio de Janeiro: Paz e Terra, 1978.

MELLO, Celso Antônio Bandeira de. Conteúdo jurídico do princípio da igualdade. ( $3^{\mathrm{a}} \mathrm{ed}$. - 12 $2^{\mathrm{a}}$ tiragem). São Paulo : Malheiros, 2005.

PADRÓS, Enrique Serra; FERNANDES, Ananda Simões. A gestação do golpe no Uruguai: o governo Bordaberry e o papel dos militares (1972-1973). Estudos Ibero-americanos: PUCRS, Porto Alegre, v. 38, n. 1, p.27-44, 2012. Disponível em:

$<$ http://revistaseletronicas.pucrs.br/ojs/index.php/iberoamericana/article/view/11584/8009>. Acesso em: 14 maio 2018.

SCHILL, Jeremy. Blackwater: a ascensão do exército mais poderoso do mundo. São Paulo : Companhia das Letras, 2008.

SHAKESPEARE, W. Hamlet, príncipe da Dinamarca. Tradução de Ana Amélia de Queiroz Carneiro Mendonça. In: BLOOM, H. Hamlet: poema ilimitado. Tradução de José Roberto O'Shea. Rio de Janeiro: Objetiva, 2004. p.140-319.

SOARES, M. L. Q. Teoria do Estado: novos paradigmas em face da globalização. 4. ed. São Paulo: Atlas, 2011.

SKINNER, Quentin. As fundações do pensamento político moderno. São Paulo : Companhia das Letras, 1996.

VATTIMO, Gianni. A filosofia e o declínio do Ocidente. IN : MARTINS, Francisco Menezes; SILVA, JUREMIR Machado da (org.). Para navegar no século XXI: tecnologias do imaginário e cibercutura. $3^{\text {a }}$ Ed. Porto Alegre : Sulina/Edipucrs, 2003, p. 49-63.

VIRILIO, P. Velocidade e Política. São Paulo: Estação Liberdade, 1996.

WEBER, MAX. Ensaios de Sociologia. Rio de Janeiro : Zahar Editores, 1979. 